\title{
RESEARCH
}

Open Access

\section{The dual allelopathic capacity of two Brassicaceae plants' seed powder in controlling Orobanche crenata infesting Pisum sativum as well as stimulating its growth and yield}

\author{
Salah El-Din Abd El-Ghany Ahmed, Nadia Khalil Messiha, Raafat Ragheb El-Masry and \\ Mahmoud Ahmed Touny El-Dabaa* (1)
}

\begin{abstract}
Background: It is well known that legume and other crops such as pea, faba bean, lentil, chick pea, and several other crops are susceptible to Orobanche crenata (broomrape) infestation. There is a direct relationship between 0 . crenata infestation and yield losses depending on the severity of infestation, the crop sensitivity, the planting date, and the different prevailing environmental factors. So, the present investigation aims to evaluate the allelopathic potentiality of the seed powder of the Brassicaceae plants (Eruca sativa and Sinapis alba) in controlling O. crenata infesting Pisum sativum plants.

Materials/methods: Two greenhouse experiments were held during two consecutive winter seasons to study the allelopathic effect of Eruca sativa (Essp) and Sinapis alba (Sasp) seed powder and compare it with recommended Basamid (Dazomet) herbicide treatment in controlling O. crenata infesting Pisum sativum as well as their effect on $P$. sativum growth, yield, and yield attributes. The treatments were conducted by mixing the seed powder of $E$. sativa (Essp) or S. alba (Sasp) to the soil at 12.5, 25.0, 37.5, and $50 \mathrm{~g} / \mathrm{kg}$ soil as well as Basamid herbicide at $0.2 \mathrm{~g} / \mathrm{pot}$.

Results: The recorded results show that both Essp and Sasp at successive rates as well as Basamid treatment scored a great inhibition in dry weight of $O$. crenata tubercles infesting $P$. sativum plants at 55 days after sowing (DAS) and at harvest. The highest rate $(50 \mathrm{~g} / \mathrm{kg})$ of both applied seed powder achieved the highest level of controlling $O$. crenata investigated weed. Growth as well as yield and yield attributes of $P$. sativum increased by the application of Essp and Sasp especially at the lowest rates in comparison with infected control.

Conclusion: The lowest rates (12.5 and $25 \mathrm{~g} / \mathrm{kg}$ soil) of both Essp and Sasp were the optimum applied treatments that suppressed $O$. crenata weed with the highest yield of $P$. sativum as compared with the healthy control. Glucosinolates and phenolic compounds in both seed powder may be the main active allelochemical which could be considered as a natural bioherbicide for controlling the $O$. crenata parasitic weed that infests $P$. sativum and reflected in turn on the plant yield by increase.
\end{abstract}

Keywords: Allelopathy, Eruca sativa, Sinapis alba, Glucosinolates, Phenolic contents, Pisum sativum, Orobanche crenata

\footnotetext{
* Correspondence: eldabaam@yahoo.com

Botany Department, Weed Biology and Control, National Research Centre, 33 El Bohouth St. Dokki, P.O. Box 12622, Cairo, Egypt
} 


\section{Background}

Orobanche crenata (broomrape) is a parasitic weed on legume and other crops such as pea, chick pea, faba bean, lentil, common vetch, and several crops (Messiha et al. 2004; Hershenhorn et al. 2009). O. crenata parasitic weed is widespread in Middle East, Southern Europe, and Mediterranean region (Kandil et al. 2015). The leguminous yield losses due to O. crenata infestation depend on variation of dominant environmental factors, brutality of infection, and sowing date (Rubiales et al. 2009; Kandil et al. 2015). The difficulty in controlling Orobanche spp. in leguminous is related to several agents such as its location from the soil surface, host plant roots penetration, complicated mechanisms of seed dispersion, germination, and permanence (Linke and Saxena 1991). Recently, many strategies have been developed aiming to control $O$. crenata parasitic weed either chemically or biologically beside the cultural practices (Rubiales et al. 2009; Fernandez-Aparicio et al. 2011; Messiha et al. 2018; ElDabaa et al. 2019; El-Masry et al. 2019).

Pea (Pisum sativum L.) is a well-known vegetable and belongs to the family Leguminosae. It is a major ingredient of vegetarian diets and meets the food requirements of people all over the world. It contains most essential nutrients like starch, protein, and fiber and has significant amounts of vitamins and minerals and is characterized by a relatively high antioxidant activity (Han and Baik 2008). Pea is one of leguminous plants which infested by $O$. crenata that causes severe loss of the plant yield.

The recent approaches in agricultural production are trying to use natural and safe substances to compete weeds, insects, nematodes, etc., to decrease the harmful effects of synthetic chemicals (like herbicides, insecticides, nematicides, and fungicides) and at the same time improve the quality and increase the production of different crops. Allelopathy is the phenomenon where natural compounds are released from the different parts of the plant such as roots, shoots, leaves, or flowers which affect other plants (Rice 1995) and can be used as a safe approach for controlling some weeds. Many higher plant species have been approved to have chemicals accompanied with the allelopathic properties; these allelochemicals are released into surrounding areas either by exudation or leaching or through decomposition of plant residues that affect the neighboring plants (Einhellig 2004). These neighboring receptor plants are positively or negatively affected by the allelochemicals (Zhou et al. 2011). In different allelopathic plants, allelochemicals such as flavonoids, terpenoids, alkaloids, glucosinolates, phenolic compounds, and amino acids were found (Fahey et al. 2001; Velasco et al. 2008).

Brassicaceae family is reported to have allelochemicals that improved its inhibitory effect on weed growth and hence received great attention to be applied as a safe controlling method (Fenwick et al. 1983; Velasco et al. 2008; Zaji and Majd 2011; Martinez-Ballesta et al. 2013; El-Wakeel et al. 2019). The allelochemicals that are produced in abundant amount in Brassica sp. tissues are known as glucosinolates. As the plant tissues are disrupted, the myrosinase enzyme acts to hydrolyze glucosinolates to several degradable products, i.e., nitriles, isothiocyanates, thiocyanates, oxazoliolines, and epithionitriles (Bones and Rossiter 2006). Isothiocyanates are the main degradable products that are phytotoxic (Fenwick et al. 1983; Fahey et al. 2001; Zaji and Majd 2011; Martinez-Ballesta et al. 2013) and have pesticidal activities (Velasco et al. 2008). Many scientists have been improved that seeds of Brassicaceae contain an abundant amount of glucosinolates that are higher than any other part of plants (Fahey et al. 2001; Velasco et al. 2008).

So, the present investigation is applied to evaluate the allelopathic potentiality of two seed powder of the Brassicaceae plants (Eruca sativa and Sinapis alba) in controlling Orobanche crenata infesting Pisum sativum plants.

\section{Materials and methods}

Two pot experiments were carried out during two successive winter seasons of 2016/2017 and 2017/2018 at the greenhouse of the National Research Centre, Dokki, Giza, Egypt. Pea (Pisum sativum) seeds (cv. Master B) and seeds of both watercress (Eruca sativa) and white mustard (Sinapis alba) were obtained from the Agricultural Research Centre, Giza, while parasitic weed seeds of Orobanche crenata (broomrape) were obtained from the Weed Control Section, Ministry of Agric., Giza, Egypt. Clean seeds of both E. sativa and S. alba were grinded to fine powder and immediately incorporated to the soil surface before sowing at the rate of $0,12.5,25.0,37.5$, and 50 $\mathrm{g} / \mathrm{kg}$ soil. The experiment consisted of 11 treatments, including two controls (healthy and infected). Each treatment is represented by nine pots. All treatments, except healthy control, were infected with $O$. crenata seeds $(0.2$ $\mathrm{g} /$ pot) at 5 -cm depth from the soil surface. The experiment also includes herbicidal treatment with Basamid (Dazomet) for comparison with the allelopathic effect of both E. sativa and $S$. alba treatments. Basamid granules (tetrahydro-3, 5-dimethyl-2H-1, 3, 5-thiadiazine 2-thione) were mixed in the soil infected with $O$. crenata seeds $(0.2$ $\mathrm{g} / \mathrm{pot}$ ) at 5-cm depth from the soil surface. After 2 weeks, $P$. sativum seeds (8 seeds/pot) were sown on November 27 and 26 in the first and second seasons, respectively, 3 $\mathrm{cm}$ deep in pots with a $30-\mathrm{cm}$ diameter $\left(0.07 \mathrm{~m}^{2}\right)$ filled with $5 \mathrm{~kg}$ clay and sandy soil $(2,1)$. Two weeks later, the $P$. sativum plants were thinned to 4 plants/pot. All treatments were distributed in a complete randomized design. The normal cultural practices of growing $P$. sativum plants were followed especially fertilization and irrigation. 


\section{Characters studied Weed growth characters}

In each season, three replicates were collected from each treatment at 55 days after sowing (DAS) and at harvest. The numbers as well as fresh and dry weight of $O$. crenata tubercles/pot (g) were recorded at the two growth ages, while $O$. crenata tubercles length $(\mathrm{cm})$ was recorded at harvest only.

\section{Plant growth}

In both seasons, samples of $P$. sativum plants were collected from each treatment at 30, 55, and 90 days after sowing (DAS) to determine the shoot height $(\mathrm{cm})$, root length $(\mathrm{cm})$, number of leaves/plant, number of branches/plant, and fresh and dry weight of plant (g).

\section{Yield and yield attributes}

At harvest, samples of $P$. sativum plants were taken from each treatment to determine the number of pods/plant, fresh weight of pods/plant (g), dry weight of pods/plant, and number of seeds/pod.

\section{Chemical analysis}

\section{Total glucosinolates ( $\mu \mathrm{mol} / \mathrm{g} D W$ )}

Total glucosinolates were extracted from dry samples of seed powder of both E. sativa and S. alba. Glucosinolates were measured by determining the liberated glucose which was released during hydrolysis by myrosinase enzyme (Rauchberger et al. 1979). The resulting glucose was determined colorimetrically according to the methods defined by Nasirullah (1996).

\section{Total phenolic contents ( $\mathrm{mg} / \mathrm{g} \mathrm{DW}$ )}

Total phenolic contents of both $E$. sativa and $S$. alba seeds were determined colorimetrically using Folin and Ciocalteu phenol reagent according to the method defined by Snell and Snell (1953).

\section{Statistical analysis}

All data were statistically analyzed according to Snedecor and Cochran (1980), and the treatment means were compared by using LSD at $5 \%$ level of probability.

The data obtained were subjected to analysis of variance (ANOVA) according to Snedecor and Cochran (1980) using the CoStat Software Program Version 6.303 (2004), and LSD at 0.05 level of significance was used for the comparison 140 between means.

\section{Results}

\section{Characteristics of weed growth}

The results in Table 1 appeared the efficiency of the investigated Eruca sativa (Essp) and Sinapis alba (Sasp) seed powder at successive rates (12.5 to $50 \mathrm{~g} / \mathrm{kg}$ soil), and Basamid herbicide at $0.2 \mathrm{~g} / \mathrm{kg}$ soil scored a significant inhibitory effect on Orobanche crenata infesting Pisum sativum plants. This inhibitory effect could be represented in the number and fresh and dry weight of O. crenata tubercles/pot at both ages (55 DAS and at harvest) comparing with their corresponding infected control. The reduction

Table 1 Effect of different rates of both Eruca sativa and Sinapis alba seed powder and herbicide Basamid on Orobanche crenata tubercles at 55 days after sowing and at harvest of Pisum sativum (combined analysis of two seasons)

\begin{tabular}{|c|c|c|c|c|c|c|c|}
\hline \multirow[t]{2}{*}{ Treatments } & \multicolumn{3}{|c|}{ At 55 days after sowing } & \multicolumn{4}{|l|}{ At harvest } \\
\hline & $\begin{array}{l}\text { No. of } 0 . \text { crenata } \\
\text { tubercles/pot }\end{array}$ & $\begin{array}{l}\text { Fresh weight of } \\
\text { O. crenata/pot (g) }\end{array}$ & $\begin{array}{l}\text { Dry weight of } 0 . \\
\text { crenata/pot }(\mathrm{g})\end{array}$ & $\begin{array}{l}\text { No. of } 0 . \text { crenata } \\
\text { tubercles/pot }\end{array}$ & $\begin{array}{l}\text { Fresh weight } \\
\text { of } 0 \text {. crenatal } \\
\text { pot (g) }\end{array}$ & $\begin{array}{l}\text { Dry weight } \\
\text { of } 0 . \text { crenatal } \\
\text { pot (g) }\end{array}$ & $\begin{array}{l}\text { Length of } \\
\text { O. crenata } \\
\text { tubercles }(\mathrm{cm})\end{array}$ \\
\hline $\begin{array}{l}\text { Pisum sativum }(P .)+ \\
\text { Orobanche crenata }(O .)\end{array}$ & 58.5 & 21.30 & 4.15 & 62.0 & 40.50 & 5.90 & 7.50 \\
\hline $\begin{array}{l}\text { P. }+ \text { O. + Basamid at } \\
0.2 \mathrm{~g} / \text { pot }\end{array}$ & 19.0 & 7.55 & 1.47 & 6.5 & 5.50 & 0.54 & 3.25 \\
\hline $\begin{array}{l}\text { P. }+ \text { O. }+ \text { Eruca sativa (E.) } \\
\text { at } 12.5 \mathrm{~g} / \mathrm{kg} \text { soil }\end{array}$ & 28.0 & 7.70 & 1.50 & 4.0 & 3.85 & 0.37 & 3.62 \\
\hline P. + O. E. at $25 \mathrm{~g} / \mathrm{kg}$ soil & 4.0 & 0.65 & 0.11 & 3.0 & 2.50 & 0.32 & 2.83 \\
\hline P. + O. + E. at $37.5 \mathrm{~g} / \mathrm{kg}$ soil & 3. 0 & 0.42 & 0.09 & 2.0 & 2.40 & 0.16 & 2.00 \\
\hline P. + O. + E. at $50 \mathrm{~g} / \mathrm{kg}$ soil & 1.0 & 0.08 & 0.02 & 1.0 & 2.05 & 0.10 & 1.00 \\
\hline $\begin{array}{l}\text { P. }+ \text { O. }+ \text { Sinapis alba (S.) } \\
\text { at } 12.5 \mathrm{~g} / \mathrm{kg} \text { soil }\end{array}$ & 31.0 & 13.85 & 2.70 & 6.0 & 7.40 & 0.72 & 3.68 \\
\hline P. + O. + S. at $25 \mathrm{~g} / \mathrm{kg}$ soil & 25.0 & 6.60 & 1.29 & 5.0 & 4.60 & 0.45 & 3.18 \\
\hline P. + O. + S. at $37.5 \mathrm{~g} / \mathrm{kg}$ soil & 2.5 & 1.95 & 0.38 & 3.0 & 1.20 & 0.20 & 3.00 \\
\hline P. + O. + S. at $50 \mathrm{~g} / \mathrm{kg}$ soil & 1.0 & 0.12 & 0.02 & 1.0 & 0.30 & 0.10 & 1.67 \\
\hline LSD at $5 \%$ & 1.8 & 0.78 & 0.33 & 1.5 & 0.85 & 0.21 & 0.79 \\
\hline
\end{tabular}

P. Pisum sativum, O. Orobanche crenata, E. Eruca sativa, S. Sinapis alba 
in $O$. crenata characteristics at the two ages was rate dependent. Optimum reduction in growth parameters of $O$. crenata tubercles/pot was recorded with the highest Essp and Sasp rates $(50 \mathrm{~g} / \mathrm{kg}$ soil $)$ at the two ages of growth in comparison with their corresponding infected control. The highest decrease of $O$. crenata tubercles dry weight at harvest was found with $50 \mathrm{~g} / \mathrm{kg}$ soil rate of Essp and Sasp, reached to $98.31 \%$, for both materials as compared with their corresponding infected control. These superior treatments achieved better results than Basamid treatment at $0.2 \mathrm{~g} /$ pot in controlling O. crenata parasitizing P. sativum.

\section{Growth of Pisum sativum}

The recorded results in Tables 2, 3, and 4 indicated that most growth characters of $P$. sativum such as shoot height $(\mathrm{cm})$, root length $(\mathrm{cm})$, number of leaves/plant, number of branches/plant, and fresh and dry weight of plant (g) at 30,55 , and 90 DAS were significantly stimulated by treating with all Essp and Sasp successive rates (12.5 to $50 \mathrm{~g} / \mathrm{kg}$ soil) and Basamid treatment at $0.2 \mathrm{~g} /$ pot at the three growth ages, i.e., 30, 55, and 90 DAS as compared with their corresponding infected control. The lowest rate $(12.5 \mathrm{~g} / \mathrm{kg}$ soil) of both incorporated materials (Essp and Sasp) recorded the highest significant increases in the investigated growth parameters as compared with healthy control and recommended the herbicidal Basamid treatment at different growth ages. At 90 DAS, both Essp and Sasp at $12.5 \mathrm{~g} / \mathrm{kg}$ soil rate recorded maximum increases in the total dry weight of the $P$. sativum plant which amounted to 9.25 and $7.71 \%$ respectively more than the corresponding healthy control, whereas the infestation with $O$. crenata caused reduction in the $P$. sativum dry weight which reached to $55.27 \%$ at the same growth age compared with the healthy control.

\section{Pisum sativum yield}

The results of yield and yield attributes of $P$. sativum at harvest such as the number of pods/plant, fresh and dry weight of pods/plant, and number of seeds/pod are recorded in Table 5. All these yield parameters significantly increased by the application of Essp and Sasp at successive rates (12.5 to $50 \mathrm{~g} / \mathrm{kg}$ soil) and Basamid treatment at $0.2 \mathrm{~g} /$ pot as compared with untreated infected controls. Incorporating the soil with Essp and Sasp at 12.5 and $25 \mathrm{~g} / \mathrm{kg}$ soil rates as well as $0.2 \mathrm{~g} /$ pot soil Basamid herbicide was the superior treatments in developing $P$. sativum yield and yield attributes.

Not only the lowest applied treatment $(12.5 \mathrm{~g} / \mathrm{kg}$ soil $)$ of both Essp and Sasp alleviated the harmful effect of $O$. crenata infesting P. sativum which amounted to $74.27 \%$ as shown in the dry weight of pods/plant, but also increased this character to reach to 30.58 and $14.08 \%$, respectively, over the corresponding healthy control. It is clear from the results of Essp at $12.5 \mathrm{~g} / \mathrm{kg}$ soil rate induced increase in the dry weight of pods/plant amounted to more than the double of that recorded with the same rate of Sasp in the same yield parameters $(30.58,14.08)$. It should be noted that the use of both Essp and Sasp at $12.5 \mathrm{~g} / \mathrm{kg}$ soil rate induced increases which exceed that caused by the herbicidal effect of Basamid herbicide $(0.2 \mathrm{~g} / \mathrm{pot})$ in all $P$. sativum yield and yield attributes.

Table 2 Effect of different rates of both Eruca sativa and Sinapis alba seed powder and herbicide Basamid on growth parameters of Pisum sativum at 30 days after sowing (combined analysis of two seasons)

\begin{tabular}{|c|c|c|c|c|c|c|}
\hline \multirow[t]{2}{*}{ Treatments } & \multicolumn{6}{|c|}{ Growth parameters } \\
\hline & $\begin{array}{l}\text { Shoot height of } \\
\text { plant }(\mathrm{cm})\end{array}$ & Root length $(\mathrm{cm})$ & No. of leaves/plant & No. of branches/plant & F.W. of plant (g) & D.W. of plant (g) \\
\hline Pisum sativum $(P)$. & 44.6 & 10.8 & 8.8 & 1.27 & 5.68 & 1.15 \\
\hline $\begin{array}{l}\text { Pisum sativum (P.) + Orobanche } \\
\text { crenata }(O .)\end{array}$ & 27.8 & 6.4 & 6.8 & 1.01 & 2.34 & 0.46 \\
\hline P. + O. + Basamid at $0.2 \mathrm{~g} / \mathrm{pot}$ & 43.5 & 10.6 & 8.4 & 1.24 & 5.56 & 1.11 \\
\hline $\begin{array}{l}\text { P. }+ \text { O. + Eruca sativa (E.) at } \\
12.5 \mathrm{~g} / \mathrm{kg} \text { soil }\end{array}$ & 63.0 & 15.3 & 10.2 & 1.39 & 8.64 & 1.61 \\
\hline P. + O. +E. at $25 \mathrm{~g} / \mathrm{kg}$ soil & 51.8 & 13.3 & 9.7 & 1.32 & 6.88 & 1.34 \\
\hline P. + O. + E. at $37.5 \mathrm{~g} / \mathrm{kg}$ soil & 43.0 & 10.2 & 8.2 & 1.22 & 5.39 & 1.10 \\
\hline P. + O. + E. at $50 \mathrm{~g} / \mathrm{kg}$ soil & 37.2 & 9.8 & 8.0 & 1.18 & 5.26 & 1.03 \\
\hline $\begin{array}{l}\text { P. }+ \text { O. + Sinapis alba }(S .) \text { at } \\
12.5 \mathrm{~g} / \mathrm{kg} \text { soil }\end{array}$ & 53.0 & 13.3 & 9.8 & 1.35 & 8.08 & 1.53 \\
\hline P. + O. + S. at $25 \mathrm{~g} / \mathrm{kg}$ soil & 48.3 & 13.0 & 9.3 & 1.30 & 6.62 & 1.31 \\
\hline P. + O. + S. at $37.5 \mathrm{~g} / \mathrm{kg}$ soil & 33.2 & 8.7 & 7.7 & 1.15 & 4.55 & 0.91 \\
\hline P. + O. + S. at $50 \mathrm{~g} / \mathrm{kg}$ soil & 32.2 & 6.9 & 7.6 & 1.11 & 3.82 & 0.77 \\
\hline LSD at $5 \%$ & 2.14 & 1.38 & 1.06 & 0.15 & 1.10 & 0.12 \\
\hline
\end{tabular}

P. Pisum sativum, O. Orobanche crenata, E. Eruca sativa, S. Sinapis alba 
Table 3 Effect of different rates of both Eruca sativa and Sinapis alba seed powder and herbicide Basamid on growth parameters of Pisum sativum at 55 days after sowing (combined analysis of two seasons)

\begin{tabular}{|c|c|c|c|c|c|c|}
\hline \multirow[t]{2}{*}{ Treatments } & \multicolumn{6}{|c|}{ Growth parameters } \\
\hline & $\begin{array}{l}\text { Shoot height of } \\
\text { plant }(\mathrm{cm})\end{array}$ & Root length $(\mathrm{cm})$ & No. of leaves/plant & No. of branches/plant & F.W. of plant (g) & D.W. of plant (g) \\
\hline Pisum sativum $(P)$. & 57.8 & 13.3 & 13.2 & 1.55 & 9.20 & 4.03 \\
\hline $\begin{array}{l}\text { Pisum sativum }(P .)+\text { Orobanche } \\
\text { crenata }(O .)\end{array}$ & 45.0 & 8.8 & 10.1 & 1.11 & 5.65 & 1.59 \\
\hline P. + O. + Basamid at $0.2 \mathrm{~g} / \mathrm{pot}$ & 57.3 & 12.3 & 13.0 & 1.53 & 9.02 & 3.69 \\
\hline $\begin{array}{l}\text { P. }+ \text { O. + Eruca sativa }(E .) \text { at } \\
12.5 \mathrm{~g} / \mathrm{kg} \text { soil }\end{array}$ & 69.3 & 17.5 & 14.7 & 1.74 & 13.68 & 5.05 \\
\hline P. + O. E. at $25 \mathrm{~g} / \mathrm{kg}$ soil & 63.3 & 14.2 & 14.0 & 1.65 & 11.04 & 4.79 \\
\hline$P .+O .+E$. at $37.5 \mathrm{~g} / \mathrm{kg}$ soil & 55.3 & 11.5 & 12.8 & 1.35 & 8.68 & 3.52 \\
\hline P. +O. E. at $50 \mathrm{~g} / \mathrm{kg}$ soil & 54.5 & 11.2 & 12.5 & 1.29 & 8.32 & 3.46 \\
\hline $\begin{array}{l}\text { P. }+ \text { O. + Sinapis alba (S.) at } \\
12.5 \mathrm{~g} / \mathrm{kg} \text { soil }\end{array}$ & 63.8 & 16.0 & 14.6 & 1.69 & 12.79 & 4.90 \\
\hline P. + O. + S. at $25 \mathrm{~g} / \mathrm{kg}$ soil & 59.7 & 14.0 & 13.7 & 1.58 & 9.54 & 4.60 \\
\hline P. + O. + S. at $37.5 \mathrm{~g} / \mathrm{kg}$ soil & 50.5 & 9.8 & 12.1 & 1.21 & 7.15 & 2.94 \\
\hline P. + O. + S. at $50 \mathrm{~g} / \mathrm{kg}$ soil & 45.8 & 9.0 & 11.5 & 1.19 & 7.02 & 2.90 \\
\hline LSD at $5 \%$ & 1.71 & 1.52 & 1.14 & 0.17 & 1.44 & 0.86 \\
\hline
\end{tabular}

P. Pisum sativum, O. Orobanche crenata, E. Eruca sativa, S. Sinapis alba

\section{Quantitative estimation of total glucosinolates and total phenolic contents in Eruca sativa and Sinapis alba seed powder}

Table 6 shows the quantity of total glucosinolates (316.03 and $288.59 \mu \mathrm{mol} / \mathrm{g}$ dry weight) and total phenolic contents ( 35.62 and $43.62 \mathrm{mg} / \mathrm{g}$ dry weight) in the seed powder of E. sativa and $S$. alba, respectively.

\section{Discussion}

Modern researches seek to apply the allelopathic approach as a nonchemical safe method to suppress the competitor weeds. Our previous studies ensured allelopathic efficiency of seed powder of some Brassicaceae plants such as Raphanus sativus, Sinapis alba, Eruca sativa, and Brassica rapa in controlling some annual and perennial weeds (Messiha et al. 2013; Ahmed et al.

Table 4 Effect of different rates of both Eruca sativa and Sinapis alba seed powder and herbicide Basamid on growth parameters of Pisum sativum at 90 days after sowing (combined analysis of two seasons)

\begin{tabular}{|c|c|c|c|c|c|c|}
\hline \multirow[t]{2}{*}{ Treatments } & \multicolumn{6}{|c|}{ Growth parameters } \\
\hline & $\begin{array}{l}\text { Shoot height of } \\
\text { plant }(\mathrm{cm})\end{array}$ & Root length $(\mathrm{cm})$ & No. of leaves/plant & No. of branches/plant & F.W. of plant (g) & D.W. of plant (g) \\
\hline Pisum sativum (P.) & 60.8 & 13.7 & 13.7 & 2.32 & 6.86 & 3.89 \\
\hline $\begin{array}{l}\text { Pisum sativum }(P .)+\text { Orobanche } \\
\text { crenata }(O .)\end{array}$ & 48.3 & 9.2 & 10.6 & 1.18 & 3.52 & 1.74 \\
\hline P. + O. + Basamid at $0.2 \mathrm{~g} / \mathrm{pot}$ & 60.7 & 12.9 & 13.4 & 2.29 & 6.64 & 3.55 \\
\hline $\begin{array}{l}\text { P. }+ \text { O. + Eruca sativa (E.) at } \\
12.5 \mathrm{~g} / \mathrm{kg} \text { soil }\end{array}$ & 72.8 & 18.8 & 16.3 & 2.56 & 7.48 & 4.25 \\
\hline P. + O. +E. at $25 \mathrm{~g} / \mathrm{kg}$ soil & 66.0 & 15.3 & 14.3 & 2.46 & 7.11 & 4.13 \\
\hline P. + O. +E. at $37.5 \mathrm{~g} / \mathrm{kg}$ soil & 58.6 & 12.6 & 13.1 & 1.93 & 6.51 & 3.46 \\
\hline P. + O. + E. at $50 \mathrm{~g} / \mathrm{kg}$ soil & 57.2 & 12.0 & 12.8 & 1.74 & 6.26 & 3.32 \\
\hline $\begin{array}{l}\text { P. }+ \text { O. + Sinapis alba }(S .) \text { at } \\
12.5 \mathrm{~g} / \mathrm{kg} \text { soil }\end{array}$ & 66.5 & 16.5 & 15.2 & 2.53 & 7.24 & 4.19 \\
\hline P. + O. + S. at $25 \mathrm{~g} / \mathrm{kg}$ soil & 61.8 & 14.5 & 14.0 & 2.40 & 7.02 & 4.08 \\
\hline P. + O. + S. at $37.5 \mathrm{~g} / \mathrm{kg}$ soil & 53.0 & 11.0 & 12.2 & 1.57 & 5.84 & 3.15 \\
\hline P. + O. + S. at $50 \mathrm{~g} / \mathrm{kg}$ soil & 51.4 & 9.7 & 11.4 & 1.33 & 5.71 & 2.94 \\
\hline LSD at $5 \%$ & 1.82 & 1.37 & 1.34 & 0.18 & 1.09 & 0.36 \\
\hline
\end{tabular}

P. Pisum sativum, O. Orobanche crenata, E. Eruca sativa, S. Sinapis alba 
Table 5 Effect of different rates of both Eruca sativa and Sinapis alba seed powder on yield and yield attributes of Pisum sativum at harvest (combined analysis of two seasons)

\begin{tabular}{|c|c|c|c|c|}
\hline \multirow[t]{2}{*}{ Treatments } & \multicolumn{4}{|c|}{ Yield and yield components of Pisum sativum } \\
\hline & Number of pods/plant & Fresh weight of pods/plant (g) & Dry weight of pods/plant (g) & Number of seeds/pod \\
\hline Pisum sativum (P.) & 4.16 & 9.49 & 2.06 & 5.25 \\
\hline $\begin{array}{l}\text { Pisum sativum }(P .)+\text { Orobanche } \\
\text { crenata }(O .)\end{array}$ & 1.59 & 2.21 & 0.53 & 2.17 \\
\hline P. + O. + Basamid at $0.2 \mathrm{~g} / \mathrm{pot}$ & 4.00 & 8.94 & 1.97 & 4.69 \\
\hline $\begin{array}{l}\text { P. }+ \text { O. + Eruca sativa (E.) at } \\
12.5 \mathrm{~g} / \mathrm{kg} \text { soil }\end{array}$ & 5.90 & 12.37 & 2.69 & 5.84 \\
\hline P. + O. + E. at $25 \mathrm{~g} / \mathrm{kg}$ soil & 4.70 & 10.06 & 2.30 & 5.41 \\
\hline P. + O. +E. at $37.5 \mathrm{~g} / \mathrm{kg}$ soil & 3.97 & 8.27 & 1.83 & 4.27 \\
\hline P. + O. +E. at $50 \mathrm{~g} / \mathrm{kg}$ soil & 3.94 & 6.74 & 1.48 & 4.08 \\
\hline $\begin{array}{l}\text { P. }+ \text { O. + Sinapis alba (S.) at } \\
12.5 \mathrm{~g} / \mathrm{kg} \text { soil }\end{array}$ & 5.53 & 10.18 & 2.35 & 5.64 \\
\hline P. + O. + S. at $25 \mathrm{~g} / \mathrm{kg}$ soil & 5.40 & 9.84 & 2.22 & 5.16 \\
\hline P. + O. + S. at $37.5 \mathrm{~g} / \mathrm{kg}$ soil & 3.90 & 4.15 & 0.93 & 3.78 \\
\hline P. + O. + S. at $50 \mathrm{~g} / \mathrm{kg}$ soil & 2.78 & 3.23 & 0.71 & 3.49 \\
\hline LSD at $5 \%$ & 0.99 & 1.02 & 0.31 & 0.85 \\
\hline
\end{tabular}

P. Pisum sativum, O. Orobanche crenata, E. Eruca sativa, S. Sinapis alba

2014, 2016; El-Masry et al. 2015; El-Rokiek et al. 2017) as well as parasitic weeds as some Orobanche species $(O$. crenata and $O$. ramosa) parasitizing faba bean and tomato plants (Messiha et al. 2018; El-Dabaa et al. 2019; El-Masry et al. 2019).

The results of the present study revealed that E. sativa and $S$. alba seed powder possess allelopathic inhibitory effect that can be utilized in controlling $O$. crenata infesting $P$. sativum plants. Incorporating Essp and Sasp to the soil at rates from 12.5 to $50 \mathrm{~g} / \mathrm{kg}$ soil negatively affected all growth parameters of $O$. crenata tubercles. The maximum rate of both materials $(50 \mathrm{~g} / \mathrm{kg}$ soil) scored the maximum reduction in all $O$. crenata parameters. Although Brassicaceae plants have the same mode of action of Basamid synthetic herbicide, both investigated Brassica species were more effective than Basamid in controlling O. crenata parasitic weed (Table 1). The mode of action depends on the induction of isothiocyanates, which recently proved its effectiveness in controlling the growth of parasitic and nonparasitic weeds (Messiha et al. 1993; Sharara et al. 2011).

It is worthy to mention that the allelopathic reducing effect of the two used materials, i.e., Essp and Sasp, on $O$. crenata growth parameters could be attributed to the

Table 6 Total glucosinolates ( $\mu \mathrm{mol} / \mathrm{g}$ dry weight) and total phenolic contents (mg/g dry weight) in the seed powder of both Eruca sativa and Sinapis alba

\begin{tabular}{lll}
\hline Materials & $\begin{array}{l}\text { Total glucosinolates } \\
(\mu \mathrm{mol} / \mathrm{g} \text { dry weight) }\end{array}$ & $\begin{array}{l}\text { Total phenolic contents } \\
(\mathrm{mg} / \mathrm{g} \text { dry weight })\end{array}$ \\
\hline Eruca sativa seed extract & 316.03 & 35.62 \\
Sinapis alba seed extract & 288.59 & 43.62 \\
\hline
\end{tabular}

natural allelochemicals mainly glucosinolates and phenolic compounds which by chemical analysis were estimated in abundant amount in both investigated plant materials (Table 5). The endogenous active myrosinase enzyme acts in hydrolyzing glucosinolates into other products mainly isothiocyanates (Fenwick et al. 1983). Isothiocyanates have been applied as pesticides for pest and disease control (Sarwar and Kirkegaard 1998) and as bioherbicides for weed control (Messiha et al. 2013, 2018; Ahmed et al. 2014, 2016; El-Masry et al. 2015; ElRokiek et al. 2017; El-Dabaa et al. 2019; El-Wakeel et al. 2019). The results of the present study indicate also that most growth parameters and yield attributes of $P$. sativum significantly increased by the application of Essp and Sasp at successive rates and the herbicidal Basamid applied at $0.2 \mathrm{~g} /$ pot (Tables 2, 3, 4, and 5). However, both 12.5 and $25 \mathrm{~g} / \mathrm{kg}$ soil Essp and Sasp and $0.2 \mathrm{~g} / \mathrm{pot}$ Basamid treatments were the effective superior treatments in controlling O. crenata parasitic weed.

It should be noted that the limitation of competitive agent between $O$. crenata weed and $P$. sativum plants induced growth parameters and consequently $P$. sativum yield (Ahmed et al. 2014; El-Rokiek et al. 2013; El-Masry et al. 2015, 2019; Jursik et al. 2015; Seshadri et al. 2015; Messiha et al. 2018). In addition, the stimulatory response of $P$. sativum plants probably related to the selective properties of the allelochemicals in their mode of action (Einhellig 1995). Allelochemicals have a selective effect that inhibits the growth of some species at a certain rate and stimulates the growth of other species at the same rate (Messiha et al. 2013, 2018; Ahmed et al. 2014; Baeshen 2014; El-Masry et al. 2015, 2019; El-Dabaa et al. 2019). 


\section{Conclusion}

Incorporating Eruca sativa or Sinapis alba seed powder to the soil is considered a safe and effective method to control Orobanche crenata parasitizing Pisum sativum and also significantly increasing the growth and yield of the plants. The most effective rates of both seed powder (12.5 and $25 \mathrm{~g} / \mathrm{kg}$ soil) are recommended to be investigated through the field level to manage Orobanche crenata infecting Pisum sativum plants.

\section{Abbreviations}

DAS: Days after sowing; Essp: Eruca sativa seed powder; 0. crenata: Orobanche crenata; P. sativum: Pisum sativum; Sasp: Sinapis alba seed powder

\section{Acknowledgements}

Thanks are due to the National Research Centre for the use of the greenhouse and laboratory facilities.

\section{Authors' contributions}

SAA participated in putting the research idea and the design of the study, participated in assembling scientific research literature, participated in practical cultivation and collecting data, performed the statistical analysis, and participated in writing and reviewing the manuscript. NKM and RRE participated in putting the research idea and the design of the study, participated in assembling scientific research literature, participated in practical cultivation and collecting data, and participated in writing and reviewing the manuscript. MATE participated in putting the research idea and the design of the study, participated in assembling scientific research literature, participated in practical cultivation and collecting data, participated in writing and reviewing the manuscript, and submitted the manuscript for publication as the corresponding author. All authors read and approved the final manuscript.

\section{Funding}

The work was self-funded by the authors.

\section{Availability of data and materials}

All data generated or analyzed during this study are included in this published article.

\section{Ethics approval and consent to participate}

Not applicable

\section{Consent for publication}

Not applicable

\section{Competing interests}

The authors declare that they have no competing interests.

Received: 14 December 2019 Accepted: 23 January 2020

Published online: 03 February 2020

\section{References}

Ahmed SA, El-Rokiek KG, El-Masry RR, Messiha NK (2014) The efficiency of allelochemicals in the seed powder of Eruca sativa in controlling weeds in Pisum sativum. Middle East J Agric Res 3(4):757-762 http://www.curresweb. com/mejar/mejar/2014/757-762.pdf

Ahmed SA, Messiha NK, El-Rokiek KG, Mohamed SA, El-Masry RR (2016) The allelopathic efficiency of two Brassicaceae plant seeds in controlling weeds associating sunflower plants. Res J Pharm Biol Chem Scis 7(5):158-165 https://www.rjpbcs.com/pdf/2016_7(5)/\%5B21\%5D.pdf

Baeshen AA (2014) Morphological and elements constituent effects of allelopathic activity of some medicinal plants extracts on Zea mays. Int Curr Res Aca Rev 2(4):135-145 http://www.ijcrar.com/vol-2-4/Areej\%20Ali\%2 OBaeshen.pdf

Bones AM, Rossiter JT (2006) The enzymic and chemically induced decomposition of glucosinolates. Phytochemistry 67:1053-1067. https://doi. org/10.1016/j.phytochem.2006.02.024
Einhellig FA (1995) Mechanism of action of allelochemical in allelopathy. In: Allelopathy organisms, processes and application. American Chemical Society, Washington, USA, pp 96-116

Einhellig FA (2004) Mode of allelochemical action of phenolic compounds. In: Macias FA, Galindo JCG, Molinillo JMG, Cutler HG (eds) Allelopathy, chemistry and mode of action of allelochemicals. (Eds.). CRC Press, BocaRaton, pp 217-239

El-Dabaa MAT, Ahmed SA, Messiha NK, El-Masry RR (2019) The allelopathic efficiency of Eruca sativa seed powder in controlling Orobanche crenata infected Vicia faba cultivar. Bulletin of the National Research Centre, pp 1-8. https://doi.org/10.1186/s42269-019-0079-9

El-Masry RR, El-Desoki ER, El-Dabaa MAT, Messiha NK, Ahmed SA (2019) Evaluating the allelopathic potentiality of seed powder of two Brassicaceae plants in controlling Orobanche ramosa parasitizing Lycopersicon esculentum Mill. Plants. Bulletin of the National Research Centre 43(101):1-8. https://doi. org/10.1186/s42269-019-0144.4

El-Masry RR, Messiha NK, El-Rokiek KG, Ahmed SA, Mohamed SA (2015) The allelopathic effect of Eruca sativa Mill. seed powder on growth and yield of Phaseolus vulgaris and associated weeds. Current Sci Intern 4:485-490 http:// www.curresweb.com/csi/csi/2015/485-490.pdf

El-Rokiek KG, Abdelhamid MT, Saad El-Din SA (2013) Physiological response of purslane weed (Portulaca oleracea) and two common beans (Phaseolus vulgaris) recombinant inbred lines to phosphorus fertilizer and bentazon herbicide. J Appl Sci Res 9(4):2743-2749

El-Rokiek KG, Ahmed SA, Messiha NK, Mohamed SA, El-Masry RR (2017) Controlling the grassy weed Avena fatua associating wheat plants with the seed powder of two Brassicaceae plants Brassica rapa and Sinapis alba. Middle East J Agric Res 6(4):1014-1020 http://www.curresweb.com/mejar/mejar/2017/1014-1020.pdf

El-Wakeel MA, Ahmed SAA, El-Desoki ER (2019) Allelopathic efficiency of Eruca sativa in controlling two weeds associated Pisum sativum plants. J Plant Protect Res 59(2):1-7. https://doi.org/10.24425/jppr.2019.129283

Fahey JW, Zalcmann AT, Talalay P (2001) The chemical diversity and distribution of glucosinolates and isothiocyanates among plants. Phytochemistry 56:5-51. https://doi.org/10.1016/s0031-9422(00)00316-2

Fenwick GR, Griffiths NM, Heaney RK (1983) Bitterness in Brussels sprouts (Brassica oleracea L. var. gemmifera): the role of glucosinolates and their breakdown products. J Sci Food Agric 34:73-80

Fernandez-Aparicio M, Westwood JH, Rubiales D (2011) Agronomic breeding and biotechnological approaches to parasitic plant management through manipulation of germination stimulant levels in agricultural soils. Botany 89: 813-826. https://doi.org/10.1139/b11-075

Han H, Baik BK (2008) Antioxidant activity and phenolic content of lentils (Lens culinaris), chickpeas (Cicer arietinum L.), peas (Pisum sativum L.) and soybeans (Glycine max) and their quantitative changes during processing. International J Food Sci Tech 43:1971-1978. https://doi.org/10.1111/j.1365-2621.2008.01800.x

Hershenhorn J, Eizenberg H, Dor E, Kapulnik Y, Goldwasser Y (2009) Phelipanche aegyptiaca management in tomato. Weed Res 49:34-47. https://doi.org/10. 1111/j.1365-3180.2009.00739.x

Jursik M, Soukup J, Holec J, Andr J, Hamouzova K (2015) Efficacy and selectivity of preemergent sunflower herbicides under different soil moisture conditions. Plant Protect Sci 51(4):214-222. https://doi.org/10.17221/82/2014-PPS

Kandil EEE, Kordy AM, Abou Zied AA (2015) New approach for controlling broomrape plants in faba bean. Alex Sci Exch J 36(3):282-291 http://alexexch. org/File/2015003603/En/1946.pdf

Linke KH, Saxena MC (1991) Study on viability and longevity of Orobanche seed under laboratory conditions, pp. 110-114. In: Wegmann K, Musselman LJ (eds) Proceedings of international workshop in Orobanche research. Eberhard- Karls- Universitat, Tubingen, Germany

Martinez-Ballesta M, Moreno DA, Carvajal M (2013) The physiological importance of glucosinolates on plant response to abiotic stress in Brassica. Int J Mol Sci 14:11607-11625. https://doi.org/10.3390/ijms140611607

Messiha NK, Ahmed SA, El-Rokiek KG, Dawood MG, El-Masry RR (2013) The physiological influence of allelochemicals in two Brassicaceae plant seeds on the growth and propagative capacity of Cyperus rotundus and Zea mays L. World Appl Sci J 26(9):1142-1149. https://doi.org/10.5829/idosi.wasj.2013.26.09.13548

Messiha NK, El Gayar SH, Mohamed SAR (1993) The efficiency of Basamid (Dazomet) in controlling purple nutsedge (Cyperus rotundus L.) in two different Egyptian soils. Egypt J Appl Sci 8(1):369-380

Messiha NK, El-Dabaa MAT, El-Masry RR, Ahmed SAA (2018) The allelopathic influence of Sinapis alba seed powder (white mustard) on the growth and yield of Vicia faba (faba bean) infected with Orobanche crenata (broomrape). Middle East J Appl Sci 8(2):418-425 http://www.curresweb.com/mejas/mejas/2018/418-425.pdf 
Messiha NK, Sharara FA, El Gayar SH (2004) Effect of glyphosate, fosamine ammonium and their mixture for controlling Orobanche crenata in pea (Pisum sativum L.). J Agric Sci Mansoura Univ 29(7):3979-3991

Nasirullah KMN (1996) A method for estimating glucosinolates in mustard/rape seeds and cake. J Sci Technol 33(6):498-500

Rauchberger Y, Mokady S, Cogan U (1979) The effect of aqueous leaching of glucosinolates on the nutritive quality of rapeseed meal. J Food Agric 30:31-39

Rice E (1995) Biological control of weeds and plant diseases. In: Advances in applied allelopathy. University of Oklahoma Press, Norman

Rubiales D, Fernandez-Aparicio M, Haddad A (2009). Parasitic weeds. In: Erskine W, Muehlbauer FJ, Sarker A, Sharma B (eds) The Lentil: Botany, Production and Uses, CAB International, Wallingford, 343-349.

Sarwar M, Kirkegaard JA (1998) Bio fumigation potential of brassicas. Plant Soil. 201:91-101

Seshadri SR, Phillip WS, Patrick WG (2015) Broadleaf weed control in sunflowe (Helianthus annuus) with preemergence-applied pyroxasulfone with and without sulfentrazone. Agricultural Sci 6:1309-1316. https://doi.org/10.4236/ as.2015.611125

Sharara FA, El-Rokiek KG, Gaweesh SS (2011) Effect of soil fumigation on growth, development, yield of wheat (Triticum aestivum L.) and associated weeds. Int J Acad Res 2:781-786

Snedecor GW, Cochran WG (1980) Statistical methods, 7th edn. The lowa State Uni. PRESS, Ames, p 507

Snell FD, Snell CT (1953) Colorimetric methods, vol 111. Organi, D. Van Nostrand Company, Inc, Toronto, New York, London, p 66

Velasco P, Soengas P, Vilar M, Cartea ME (2008) Comparison of glucosinolate profiles in leaf and seed tissues of different Brassica napus crops. J Amer Soc Hort Sci 133(4):551-558. https://doi.org/10.21273/JASHS.133.4.551

Zaji B, Majd A (2011) Allelopathic potential of canola (Brassica napus L.) residues on weed suppression and yield response of maize (Zea mays L.), International Conference on Chemical. Ecology and Environmental Sciences IICCEES, Pattaya, pp 457-460

Zhou Y, Wang Y, LIJ, Xue YJ (2011) Allelopathy of garlic root exudates. Yingyong Shengtai Xuebao 22(5):1368-1372

\section{Publisher's Note}

Springer Nature remains neutral with regard to jurisdictional claims in published maps and institutional affiliations.

\section{Submit your manuscript to a SpringerOpen ${ }^{\circ}$ journal and benefit from:}

- Convenient online submission

- Rigorous peer review

- Open access: articles freely available online

High visibility within the field

- Retaining the copyright to your article

Submit your next manuscript at $\boldsymbol{\nabla}$ springeropen.com 